scientific and operating staff. The operation of the pile is controlled by two sets of neutron-absorbing rods; the first set of rods is adjusted to keep the pile operating at a constant-power level, and the second set is available to shut the pile down in any emergency. The basic calculations for the Harwell pile were begun in 1945 by a team working under Sir John Cockeroft in the laboratories of the National Research Council of Canada, and were continued when the team moved to the newly formed Atomic Energy Research Establishment at Harwell. It was the first task of the Department of Atomic Energy at Risley, under the direction of Mr. C. Hinton, to undertake the design of the pile, based on the information provided by the Harwell team. This work began in April 1946. The actual construction of the pile was made the responsibility of the Ministry of Works, assisted by their contractors, Messrs. Chivers.

\section{Earthquakes in Japan}

Ar about 8 p.m. local time on June 28 , four severe earthquakes affected the sea and land areas around the town of Fukui, on the west coast of Honshu Island, Japan. The epicentres of the shocks appear to have been near lat. $36 \cdot 1^{\circ} \mathrm{N}$., long. $136^{\circ} \mathrm{E}$., though news from the Japanese observatories has not yet been received. An area within a radius of about 30 miles from Fukui was destructively affected. The population of Fukui (about 85,000) was largely engaged in the textile industry (mostly silk), as more than one quarter of the looms of Japan were in the town. There were some ferro-concrete buildings in the town, but most of the buildings were made of wood and these were soon set alight by the fires scattered by the shocks. The fires were difficult to check owing to earthquake damage to the water supply, and it is estimated that nearly 40,000 buildings were damaged beyond repair. A cinema collapsed, burying alive a large number of people, and many casualties were caused by falling debris at the railway station. Six other towns and thirty-nine villages in the neighbourhood were severely affected, including Marouka, Mikuni, Matsuoka, Daishoji and Kanaza. Communications were severely affected and an important railway bridge was destroyed, making relief work difficult. Huge waves lashed the coast. Altogether, some 3,200 people are believed to have lost their lives, and there are thousands of others injured. Aftershocks continued for some days.

In the whole of the densely peopled islands of Japan, there are about five hundred earthquake shocks of varying intensity every year, and although probably the greatest of the world's earthquakes have not happened there, yet there have been tremendous Japanese disasters from time to time. Examples include the Mino-Owari earthquake just after 6 a.m. local time on October 28, 1891, and the shock which almost destroyed Tokyo and Yokohama on September 1, 1923. The present shock is estimated to have been about three quarters of the strength of the latter. Between the smaller shocks of July 16-17, 1941, in the Nagano Prefecture and the shock of May 9, 1947, in Hida, there has been little news, and for part of the time some of the Japanese observatories closed down. Mr. Ernest Tillotson states that news of this period is, however, beginning to arrive: thus between December 18, 1943, and December 1945 , to the accompaniment of hundreds of seismic disturbances, a 1,200-ft. high mountain called the 'New Showa Mountain' arose with volcanic eruptions on the fringe of Lake Toya, Hokkaido, similar to the Paricutin Mountain in Mexico. Further news of these tremendous earth movements is awaited.

\section{Scientific Advisory Council to the Minister of} Fuel and Power

THE Minister of Fuel and Power has appointed the following to be members of the Scientific Advisory Council which will advise him on the scientific aspect of his statutory duties: Sir Alfred Egerton (chairman), Eng. Vice-Admiral Sir Harold Brown, Dr. H. Roxbee Cox, Sir Charles Ellis, Prof. F. H. Garner, Sir Charles Goodeve, Dr. E. S. Grumell, Mr. J. Hacking, Dr. H. Hollings, Prof. D. M. Newitt, Sir Harry Ricardo and Prof. S. Zuckerman. The terms of reference of the Council will be : (1) to advise the Minister of Fuel and Power on the scien. tific aspect of problems which he may remit to them in connexion with his statutory duty of securing the effective and co-ordinated development of coal, petroleum and other sources of fuel and power in Great Britain, and of promoting economy and efficiency in the supply, distribution, use and consumption of fuel and power, whether produced in Great Britain or not; (2) to advise the Minister of new scientific knowledge or developments which in the opinion of the Council should be taken into account in the performance of his statutory duties; (3) to keep the whole field of fuel and power under continuous review with the object of identifying problems needing scientific investigation and advising the Minister of those problems.

\section{Ordnance Survey Maps of Britain}

THE initiation/ of an entirely new ordnance map series on a scale of $1: 25,000$, or about $2 \frac{1}{2}$ inches to the mile, was one of the chief recommendations of a departmental committee set up in 1935. It was felt that the gap between the 1-inch and 6-inch was too wide for many users. In the areas already covered there are signs that the new scale is growing in popularity. Some five hundred sheets, or about one fifth of the projected total, are now published, and it is hoped that the remainder will be ready in about three years time. The new map is based on the old six-inch map, to which has been added certain revisions made for war purposes. In this sense only is it provisional : the final edition will incorporate 50-in. re-surveys of built-up areas, now in hand in many towns, and an overhaul of 25 -in. plans in rural areas. The sheet edges lie along the 10 kilometre grid lines of the national grid, and each sheet is known by the $10 \mathrm{~km}$. grid reference of its south-west cormer. The new map is sold in three styles, the fully coloured, the outline and the administrative areas. In the first, contours and main roads are in brown, water in blue, black for outlines of roads, buildings and railways, and solid black for public buildings. The outline edition is in grey monochrome without contours and is printed on specially heavy paper suitable for drawing offices. The administrative areas edition has all such boundaries shown by a red overprint on the outline edition; apparently it is being considered whether or not to continue the production of this edition. The following areas are now in the course of being covered by the $1: 25,000$ map : Greater London, Edinburgh, Glasgow, Dundee and Aberdeen; Plymouth and Dartmoor; Purbeck, New Forest, Southampton and Portsmouth, and most of the south coast; South Wales and Bristol; Gloucester, Oxford, Reading and Luton; East 